\title{
Science and philosophy
}

SIR-Emile Zuckerkandl's criticism (Nature 334, 376; 1988) of Andrew P. Whipple's even-handed approach to science and creationism (Nature 333, 492; 1988) went, in my view, off the rails. The point has surprisingly been missed that the late resurgence of 'creation science' is just part of the tactics of marketing Christianity in a consumer society in which faith has been on the wane and flagging If this point had been understood, a lot of shouting matches could have been avoided. Whipple's views are quite understandable. He argued for mutual coexistence of differing, if not contradicting, views or worldviews. The approach is a social necessity needed for peaceful coexistence. For observationally multicentred coherence, Zuckerkandl may turn to the multitude of biological researches which cannot obviously be listed in the Correspondence column. The two most important points on the issue are: (1) Science is the only course by which we know whatever we know so far about the mysteries of life; it is a process of relentless quest and the search may never end. (2) Any discrepancy or deficiency in any argument against "creation science' neither strengthens the creationist stand nor weakens the science because creationism is unable to evolve with the progress of knowledge while science is always evolving - any weakness is the arguer's.

However, when Whipple said "there is no reality beyond the physical. ..", he spoke of physical or scientific realism. Zuckerkandl's "third position" is philosophy, not science. His assertion that "the spiritual domain has a reality of its own" is acceptable but as metaphysical or philosophical realism - surrealism, perhaps. Mixing science and philosophy would be as undesirable a hotchpotch as "creation science' itself, which is a misnomer coined to attach credibility to a non-science. Philosophy, the rational and critical inquiry into basic principles of things, is distinct from science, the objectively verifiable sense perception/experience, although admittedly a clear line of demarcation may not always be possible. A simple example may illustrate my point. The idea that food contains vital minerals which is why we live and grow was philosophy; the isolation of those vital minerals (vitamins) and demonstration that they help us live and grow was science. Philosophy played in many instances a motherhood role for science.

Zuckerkandl cited 'mind' as an example, which is real but distinct from observable nature. Is not the concept of mind philosophical? By arguing for acknowledging the existence of a philosophical positions, he finally made it clear that he was talking from a philosophical platform. In the dawn of human knowledge, philosophy, science, religion, superstition, astrology, astronomy, medicine and so on were all mixed up. We have left those days behind and are looking forward to the twenty-first century. We should be able to recognize the periphery of a certain discipline even though it may often be blurred, instead of standing in the blurred area and creating a smokescreen.

\section{Wilber Street,}

Rossmoyne,

Western Australia, 6155

\section{Use of animals}

SIR-In the United Kingdom, the Animals (Scientific Procedures) Act 1986 imposes on researchers a duty to justify the use of animals in a project and then to show that the pain or distress caused is the minimum necessary. Du Pont is to sell transgenic mice that carry human oncogenes and that will develop breast cancer within a few months of birth (Nature 336, 300; 1988). How can the sale of such mice be justified under the 1986 act when it is in the interest of both patent holders and Du Pont to sell as many as possible? For many years, nude mice and mice carrying other naturally occurring genetic abnormalities have been sold, but genetic engineering provides for infinite expansion of the number and type of mutants. Selling such mutants does not seem to be the way to reduce the number of experimental animals used in research or to reduce the pain and distress caused.

MARK WORWOOD

Department of Haematology,

University Hospital of Wales,

Heath Park, Cardiff CF4 4XN, UK

\section{Reprint requests}

SIR-I recently published a short paperexactly two $7 \mathrm{in} . \times 10 \mathrm{in}$. facing sides. Reprint requests began to flood in immediately, most of them from countries where photocopiers abound. None were sent out and I have had a few pointed 'second' requests. I must assume that requests were made without sight of the paper itself. The cost of sending for this reprint and the time involved are appreciably greater than walking to the library and making a single photocopy for one's own use. The cost of despatch is an expense that those whose grants do not cover the purchase and postage of reprints can well do without.

It is some years since I, and many of my colleagues, have bought reprints, being content with the free issue only. Similarly we do not request reprints unless they contain figures that greatly lose in photocopy- ing. We can only wonder why the inveterate reprint requester has not noticed that the European reprint is a disappearing commodity. It is time that a sensible approach was taken to this problem, particularly in places where photocopiers are almost as common as journals and before scientists develop atrophy of the legs.

IVOR SMITH

Microbiology Department,

University College and Middlesex

School of Medicine,

London WIP 7LD, UK

\section{Polio in Israel}

SIR-Efforts by the Israeli health ministry to protect people in the mainland, the West Bank and Gaza against polio, which has afflicted ten victims in less than two months, have consisted of nationwide immunization of those under 40 years of age ${ }^{1}$.

This is unfortunate, as older people have never been vaccinated with inactivated or live polio vaccine. Furthermore, isolation of poliovirus from sewage samples from seven sites ${ }^{1}$ indicates that most older people in Israel have not had any exposure to wild poliovirus for some time and may well be negative for antibodies to three poliovirus strains. With virulent poliovirus present at at least seven sites, there is indeed a possibility of an epidemic in those aged 40 years and above, who deserve full immunization coverage - in the 1945 poliomyelitis epidemic in St Helena $^{2}$, there were very few cases below five years, and the maximum incidence/ mortality were confined to the higher agegroups.

Centre for Logistical

Research and Innovation,

M-122, Greater Kailash - Part II, New Delhi-110048, India

I. Nature 335. 659 (1988).

2. Gear, J.H.S. in Poliomvelitis. World Health Organization Monograph Series No 26. 31-58 (Geneva. 1955).

\section{Sense of proportion}

SIR-Anti-abortionists lose credibility when they massively overstate legitimate concerns. Thus, when Kenneth W. M. Cochran (Nature 334, 560;1988) points to the Holocaust in order to emphasize the need for governmental regulation of embryo research, he trivializes the unbearable suffering and deaths of millions caused by the Nazis (a government that certainly was strongly opposed to abortion).

To equate genocide with any lesser evil is to belittle those who suffered and to reduce the culpability of their murderers.

ARNDT vON HiPPEL.

Stone Age Press,

1649 Bannister Drive,

Anchorage, Alaska 99508, USA 